\title{
Surgical Outcome in Patients with Spontaneous Supratentorial Intracerebral Hemorrhage
}

\author{
Vladimir Rendevski1 ${ }^{1,2}$, Dragan Stojanov ${ }^{3,4}$, Boris Aleksovski ${ }^{5}$, Ana Mihajlovska Rendevska 6 , \\ Aleksandar Chaparoski ${ }^{1,2}$, Doga Ugurlar ${ }^{7}$, Vasko Aleksovski ${ }^{8}$, Natalija Baneva ${ }^{1,8}$, Icko Gjorgoski ${ }^{5}$ \\ ${ }^{1}$ Medical Faculty, "Ss. Cyril and Methodius" University, Skopje, Macedonia \\ ${ }^{2}$ University Clinic for Neurosurgery, Skopje, Macedonia \\ ${ }^{3}$ University of Niš, Faculty of Medicine, Niš, Serbia \\ ${ }^{4}$ Center of Radiology, Clinical Center Niš, Niš, Serbia \\ ${ }^{5}$ Faculty of Natural Sciences and Mathematics, "Ss. Cyril and Methodius" University, Department for General \\ Physiology and Immunology, Skopje, Macedonia \\ ${ }^{6}$ University Clinic of Radiology, Skopje, Macedonia \\ ${ }^{7}$ University of Medical Sciences Haseki Research and Training Hospital, Istanbul, Turkey \\ ${ }^{8}$ University Clinic for Neurology, Skopje, Macedonia
}

\begin{abstract}
SUMMARY
The aim of the paper was to evaluate the surgical outcome in patients with spontaneous supratentorial intracerebral hemorrhage (ICH) after surgical intervention, in respect to the initial clinical conditions, age, sex, hemispheric side and anatomic localization of ICH. Thirty-eight surgically treated patients with spontaneous supratentorial intracerebral hemorrhage were included in the study. The surgical outcome was evaluated three months after the initial admission, according to the Glasgow Outcome Scale (GOS). The surgical treatment was successful in 14 patients $(37 \%)$, whereas it was unsuccessful in 24 patients $(63 \%)$. We have detected a significant negative correlation between the Glasgow Coma Scale (GCS) scores on admission and the GOS scores after three months, suggesting worse neurological outcome in patients with initially lower GCS scores. The surgical outcome in patients with ICH was not affected by the sex, the hemispheric side and the anatomic localization of ICH, but the age of the patients was estimated as a significant factor for their functional outcome, with younger patients being more likely to be treated successfully. The surgical outcome is affected from the initial clinical state of the patients and their age. The treatment of ICH is still an unsolved clinical problem and the development of new surgical techniques with larger efficiency in the evacuation of the hematoma is necessary, thus making a minimal damage to the normal brain tissue, as well as decreasing the possibility of postoperative bleeding.
\end{abstract}

Key words: intracerebral hemorrhage, surgical outcome, Glasgow Coma Scale, Glasgow Outcome Scale

Corresponding author:

Vladimir Rendevski

Email: vladimirrendevski@yahoo.com 


\section{INTRODUCTION}

Spontaneous intracerebral hemorrhage $(\mathrm{ICH})$ is a cerebrovascular disease where a blood clot arises in the brain parenchyma in the absence of any trauma or surgery (1). It accounts for a $10-15 \%$ of all strokes (2) and represents the deadliest subtype of stroke. The mortality rate of $\mathrm{ICH}$ is $37-52 \%$ in 30 days (3) and $50 \%$ of all death cases occur within the first two days with an in-hospital mortality of $40 \%(4,5)$. One year after the hemorrhage, $74 \%$ of patients remain with severe functional inability or deceased (6). The global incidence of ICH is $10-20$ cases out of 100.000 people and it is lower in highincome countries compared to those with medium and small income, and this incidence increases with age (7-9).

Even today, still there is no proven (Phase III) medical or surgical treatment for $\mathrm{ICH}$ that could increase the survival or improve the quality of life for survivors $(10,11)$. However, although surgical treatments have demonstrated equivocal results (12), the surgical decompression for $\mathrm{ICH}$ is still widely accepted as potentially life-saving (13), because an increase in the volume of the hematoma occurs in $30 \%$ of the hospitalized patients (6) and the surgical evacuation of the hematoma can reduce the mass effect which is an important preventive measure to improve clinical outcome. Until now, the overall benefit from the surgical intervention has been only proven in patients with cerebellar ICH with GCS score of 14 or less and hematomal volume of $40 \mathrm{~mL}$ or more (14).

The aim of this study is to evaluate the surgical outcome of patients with spontaneous supratentorial $\mathrm{ICH}$ in respect to sex, age, hemispheric side, anatomical localization of the hematoma (lobar/basal ganglia) and the clinical condition.

\section{MATERIAL AND METHODS}

Thirty-eight patients with spontaneous $\mathrm{ICH}$ that underwent surgical procedure at the University clinic of Neurosurgery in Skopje during 2015 were included in our retrospective study. The study was approved by the ethical committee of the Medical Faculty in Skopje, Macedonia.

According to the defined criteria, patients with acute, primary, supratentorial $\mathrm{ICH}$, without ventricular subarachnoid flow, that underwent early surgical treatment in the first 24 hours, with hematoma over $2 \mathrm{~cm}$ in diameter from the initial brain $\mathrm{CT}$, with the condition of consciousness when admitted and evaluated according to the Glasgow Coma Scale (GCS) over 5 points were included in the study. The diagnosis of the patients, eligible with these inclusion criteria, was based on anamnesis (auto/hetero anamnesis depending on the condition of the patient's consciousness), somatic and neurological examinations and computer tomography (CT) scan of the brain.

After the diagnosis, the patients were admitted at the University clinic of Neurosurgery in Skopje (at the department of intensive care unit). Adequate medicamentous procedures were performed in order to stabilize the clinical condition of the patients and the progression of the surgical intervention. The results of the surgical treatment (i.e. the survival and functional outcome) were analyzed three months after the initial admission. The evaluation of the surgical outcome was carried out according to the Glasgow Outcome Scale (GOS) scores. The patients are classified into five categories: Class 1: good recovery, Class 2: moderate disability, Class 3: severe disability, Class 4: persistent vegetative state, Class 5: dead.

All statistical analyses were performed using Microsoft Excel 2010 and the statistical software IBM SPSS Statistics 21. Categorical variables are expressed as number of subjects and \%; the differences in the frequencies between the groups were calculated by the $\chi 2$ test. All continuous variables are expressed as mean \pm $\mathrm{SD}$ and the differences between the groups were analyzed by the Student's t-test. Bivariate statistical analyses were performed using parametric correlation with Pearson coefficient. In all cases, the level of statistical significance was defined as $\mathrm{p}<0.050$.

\section{RESULTS}

\section{Clinical state on admission and neuro- logical outcomes three months after the surgical intervention}

On admission, 12 patients (32\%) were assessed with GCS scores 6-8, i.e. in the state of coma, while 19 patients (50\%) were characterized with GCS scores 9-12 (sopor), and 7 patients (17\%) with GCS score 13-15 (somnolence or normal). As it can be seen from Figure 1, panel $\mathrm{a}$, the domination of the group of patients with sopor is obvious.

The surgical outcome was evaluated three months after the initial admission. According to the Glasgow Outcome Scale (GOS), the patients that had mild invalidity and those with a good recovery were gathered in one group of patients with successful treatment. The patients with persistent vegetative state and those with severe invalidity or deceased were gathered in the group with bad outcome. Treatment was 
successful in 14 patients (37\%), whereas it was unsuccessful in 24 patients (63\%). The domination of the group with bad outcome was, unfortunately, obvious (Figure 1, panel b). Most of the patients with somnolence were treated successfully, but unfortunately the clinical outcome for a large number of the patients with sopor was bad.

Out of the 14 patients with successful treatment, 8 patients had mild invalidity and 6 were with a good recovery. Out of the 24 patients with bad outcome, 9 patients passed away, 1 patient was in a persistent vegetative state and 14 patients were with severe invalidity.The most common postoperative complications were: bronchopneumonia (5 patients), verified rebleeding (2 patients), pulmonary embolism (1 patient) and cardiologic complications (1 patient).

The bivariate statistical analyses have revealed moderate negative correlation between the GCS scores on admission and the GOS scores after three months (Pearson coefficient $r=-0.636, p=0.000017$ ). Lower GCS scores on admission were associated with higher GOS score (worse neurological outcome) after three months, indicating that the neurological outcome is greatly affected by the initial clinical state of the patients. A regression analyses was also performed, showing moderate R2 value for the dependence of the two variables (Figure 2).
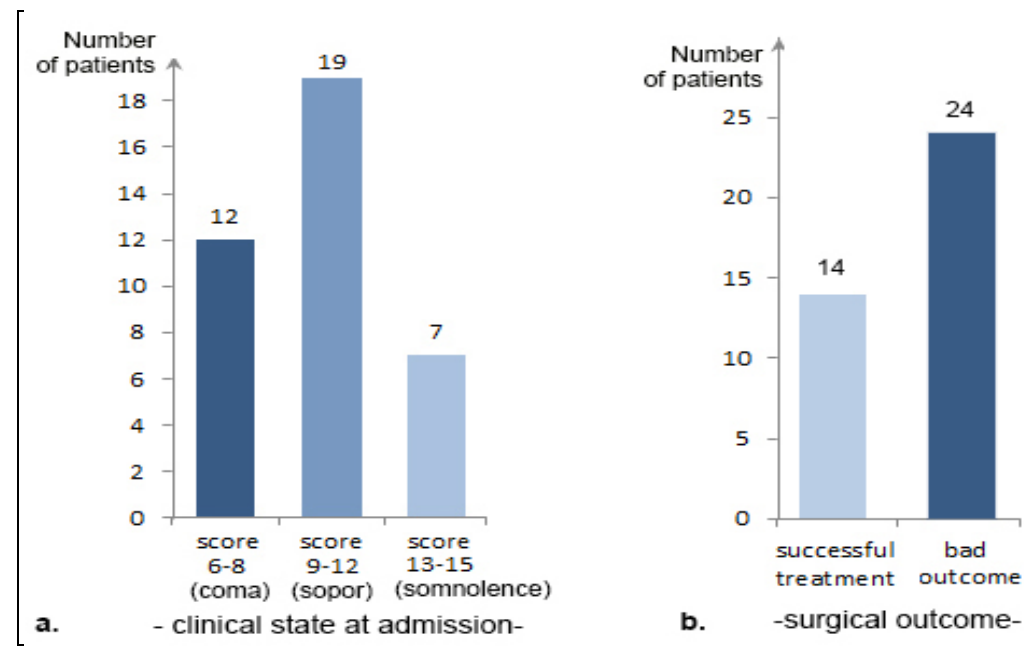

Figure 1. Distribution of the patients with $\mathrm{ICH}$ in terms of the neurological status on admission evaluated according to the GCS scores (a) and the surgical outcome three months after the intervention, according to the Glasgow Outcome Scale (GOS)

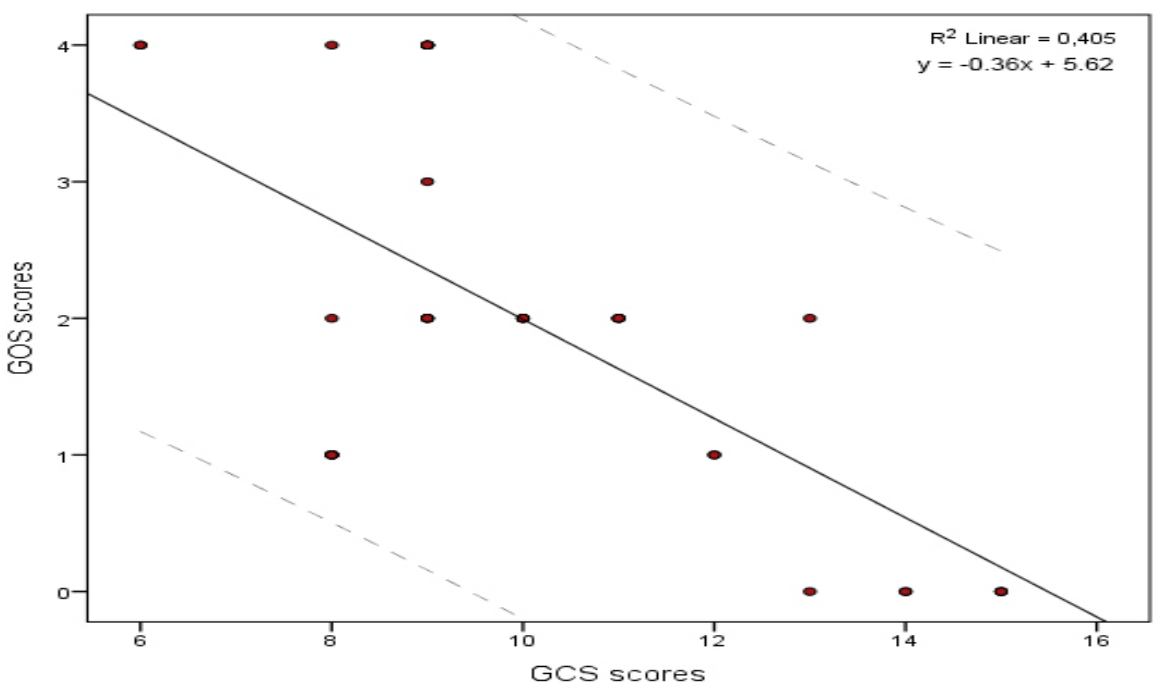

Figure 2. Regression analysis for the dependence of the GOS scores for the surgical outcome three months after the intervention from the GCS scores on admission 
Effects of age, sex, anatomic localization of ICH and hemispheric side on the surgical outcome in patients with ICH

In terms of age, a wide range of patients have entered the study (the youngest patient was 38, whereas the oldest was 78 years old). We have detected statistically significant differences in the mean age of the patients that were successfully treated (52 \pm 9 years), compared to the group with bad outcome $-62 \pm 8$ years $(t=2.57, p=0.019)$. This result points out the fact that age has a significant impact on the surgical outcome, and younger patients with ICH are more likely to be treated successfully, when compared to older patients (Figure 3).

We have also evaluated the effects of the categorical variables (sex, hemispheric side and anatomic localization of $\mathrm{ICH}$ ) on the surgical outcome in patients with ICH. Unfortunately, none of these observed variables showed significant effect on the outcome (Figure 4).

In respect to the sex, 21 male patients (55\%) and 17 female patients (45\%) participated in the study. As can be seen (Figure 4, panel a), the surgical intervention was successful in 8 male patients (57\%) and 13 female patients (54\%), whereas it was unsuccessful in 6 male patients (43\%) and 11 females (46\%). The statistical analyses proved no significant effect of the sex on their surgical outcome $(\mathrm{p}=0.859)$.

According to the hemispheric side of the hematoma, 22 patients had ICH in the right hemisphere (58\%) and 16 patients had ICH in the left hemisphere $(42 \%)$. The surgical intervention was successful in 7 patients (32\%) with right hemispheric side and 7 patients with left hemispheric side (44\%), showing no significant effect of this variable on the surgical outcome ( $p=0.452$; Figure 4, panel b).

Concerning the anatomical localization (lobar/basal ganglia), 15 cases had lobar localization of the ICH (39\%), whereas 23 patients had deep ICH in the region of the basal ganglia (61\%). With respect to neurological outcome, four patients $(27 \%)$ with lobar $\mathrm{ICH}$ and 10 patients with deep ICH were treated successfully, whereas in 11 patients with lobar ICH (73\%) and 13 patients with deep ICH (57\%) negative outcome was reported. Statistical analyses proved no significant effect of the anatomic localization on the surgical outcome $(p=0.294)$, revealing that the risk of the negative outcome is the same for both lobar and deep localization of ICH after surgical treatment (Figure 4, panel c).

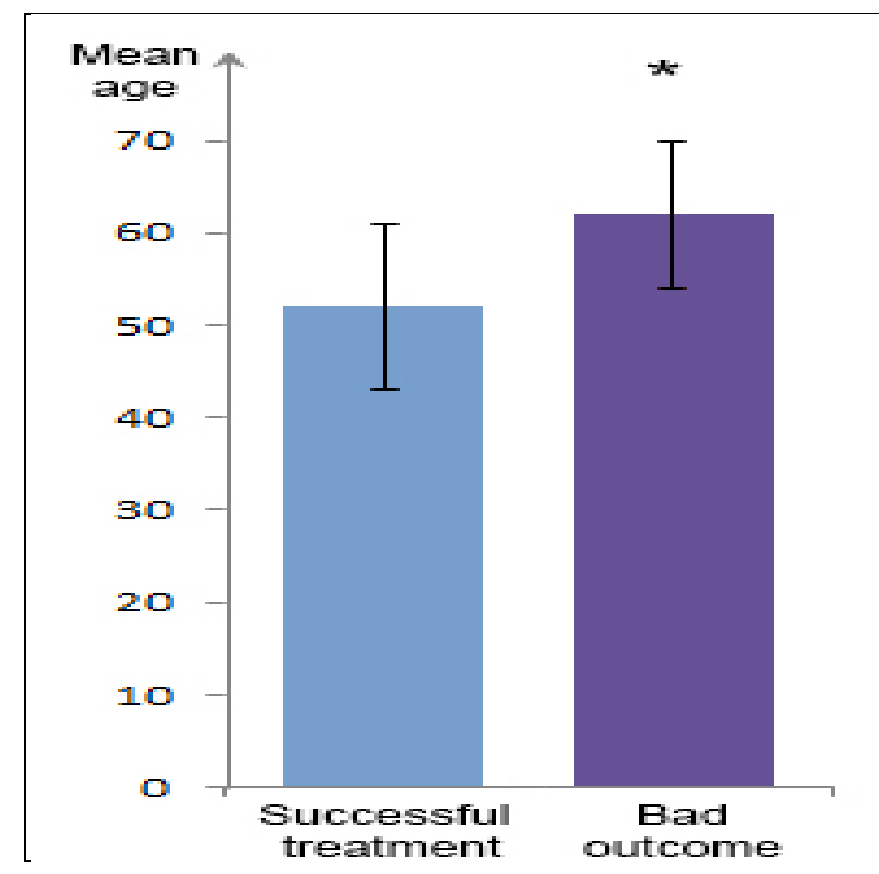

Figure 3. Effects of age on the surgical outcome in patients with ICH. Patients with successful treatment are significantly younger than patients with bad outcome. ${ }^{*} p<0 / 05$ 


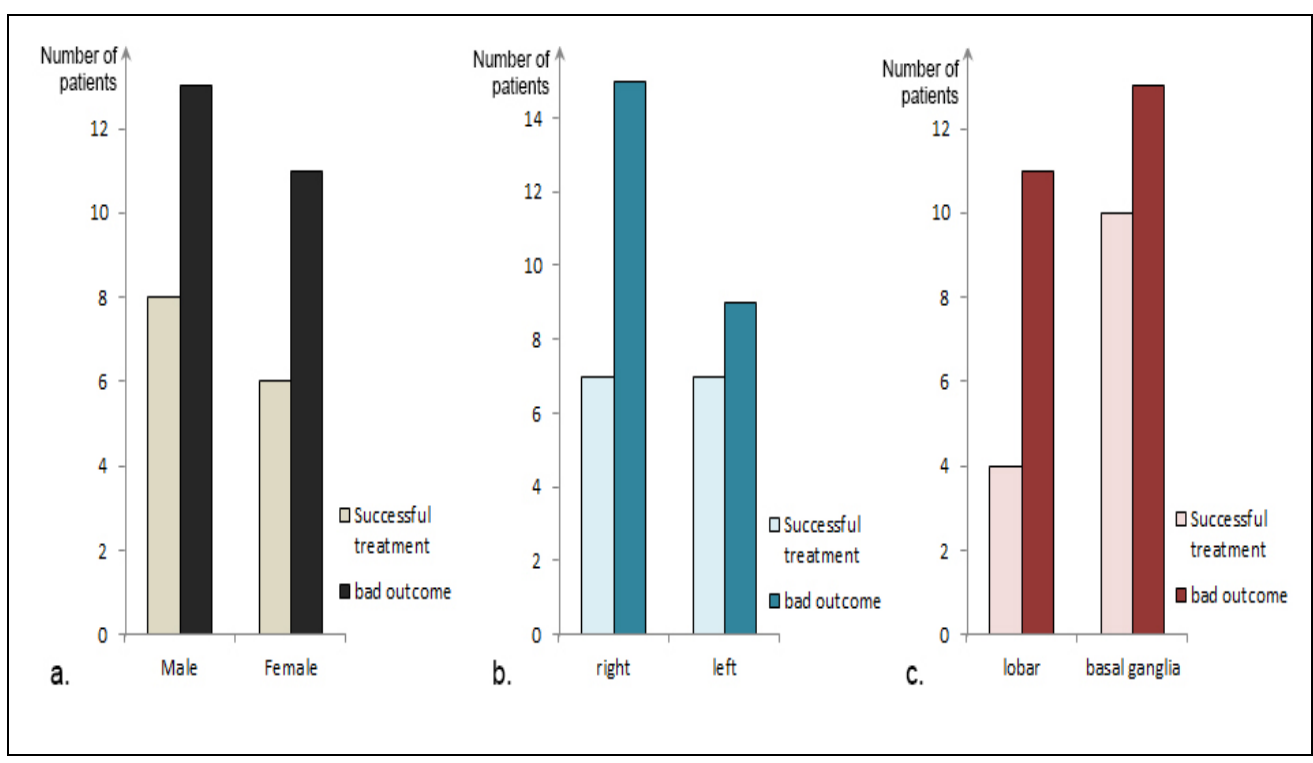

Figure 4. Effects of sex (a), hemispheric side (b) and the anatomic localization of ICH (c) on the surgical outcome in patients with ICH. There are no significant differences between the patients with successful treatment and bad outcome in each of the evaluated variables

\section{DISCUSSION}

The most important risk factor for spontaneous ICH is hypertension (15). Degenerative changes on the blood vessel wall, induced by chronic hypertension, can increase the possibility of a spontaneous rupture. The hematoma itself often leads to secondary brain injury resulting in severe neurological deficits because of the mass effect and the physical trauma (2). However, the hemorrhage also induces a series of biochemical events that include activation of the coagulation cascade, formation of hemoglobin breakdown products, oxidative stress, inflammation and blood-brain barrier permeability, and all of them contribute to the formation of perihematomal edema and secondary injury (11). The edema then can increase the intracranial pressure (ICP) and thus induce additional brain injury in the surrounding parenchyma (16). It is widely known that the supratentorial ICH is commonly accompanied by headache and vomiting as a result of the increased intracranial pressure and meningismus caused by the blood flow in the ventricles of the brain $(17,18)$.

The treatment of ICH includes two different strategies that aim to reduce these detrimental effects: conservative treatment and surgical intervention. The conservative treatment includes cardiopulmonary optimization, blood pressure control, reduction of the ICP (using hyperosmolar liquids, hyperventilation or barbiturate coma therapy), neutralization of coagulopathy and general medical approach, including careful control of glycaemia (19). The aims of surgical evacuation of the hematoma are mainly oriented towards reducing the mass effect and blockade of the release of neuropathogenic products of the hematoma, thus preventing prolonged interaction between the hematoma and the normal tissue which could initiate pathological processes. The surgical treatment options include craniotomy, stereotactic thrombolysis and/or aspiration, endoscopic lysis and/or aspiration, ventriculostomy and decompressed craniotomy or combination of the above-mentioned procedures. Until now, it was reported that patients with good neurological status (according to GCS with score of 14 or more) and with small hemorrhage (volume of the hematoma less than $40 \mathrm{ml}$ ) stand better chances for a full recovery or presence of minor invalidity during the conduction of the conservative treatment (20). Early craniotomy, on the other hand, is recommended for patients with cerebellar hematoma as the degree of neurological deterioration after cerebellar hemorrhage is very high and unpredictable.

Long years now, the questions for the benefits of early surgical intervention in contrast to the conservative treatment were raised. The scientific community was interested if better neurological outcome can be achieved with surgical intervention or conservative treatment. One of the most extensive, multi-centric, randomized and controlled study 
concerning this problematics was the STICH surgical trial - Surgical Treatment of Intracerebral Hemorrhage (21). One thousand thirty-three patients were included in the study, selected by strict inclusion criteria. As part of this project, held between January 1, 2000 and January 1, 2003, the University Clinic of Neurosurgery in Skopje was included with recruitment of $79 \mathrm{ICH}$ patients. The selection of patients was based on the principle of the socalled "clinical uncertainty" (i.e. those patients for whom the surgeon is uncertain about the possible benefits and risks of the surgical intervention). The results have shown that a satisfactory functional outcome was present in $47 \%$ of the surgically treated patients, compared to $37 \%$ of the conservatively treated patients suggesting no overall benefit of the early surgical intervention when compared to the initial conservative treatment (21).

In our study, most of the patients on admission were characterized by GCS scores of 9-12, i.e. patients with somnolence. However, three months after the surgical intervention, $63 \%$ of the patients had bad outcome, suggesting not a good benefit from the surgical treatment in patients with ICH. Although we have detected a significant and moderate correlation between the GCS cores on admission and the surgical outcome, still several patients that were characterized by better GCS scores developed bad neurological outcome after the intervention. Bearing in mind the results of the STICH study, as well as the results from our Macedonian experience, it seems that the treatment of the spontaneous ICH is still an unsolved clinical problem, despite the development of modern diagnostic, therapeutic, as well as surgical achievements.

In terms of the predictive factors that can influence the clinical outcome in patients with ICH (sex, age, hemisphere side, anatomic localization of the hematoma and clinical condition at the time of the admission), several studies have been performed, the results of which were found more or less contradictory. For instance, in a prospective study that included 166 patients with spontaneous supratentorial ICH, Daverat and colleagues (22) found that age is the key predictor of functional outcome after ICH in human beings. In this study, Daverat et al. (22) showed no significant difference between males and females in the clinical outcome; neither the hemisphere side nor the anatomic localization of the hematoma was estimated as significant variables that contribute to the clinical outcome. All of these results are in good agreement with our Macedonian experience. Contrary to these findings, in animal studies of $\mathrm{ICH}$, the sex was estimated as a significant factor for ICH-induced secondary brain injury (23).

We have shown that the surgical outcome in patients with ICH is not affected by the sex, hemispheric side and anatomic localization of ICH. It seems that both male and female patients with ICH on the left or the right hemisphere and patients with deep and lobar ICH have the same probability for bad or good outcome, when treated with surgical intervention. In contrast, the age and the clinical condition at the time of admission show significant correlation with the functional outcome in patients with $\mathrm{ICH}$. However, the neurological outcome could be also dependent on other variables that were not subject of this study, namely the volume of the hematoma, the mass effect and the presence or absence of intraventricular bleeding, which could explain the presence of a large number of patients with bad surgical outcome in our study.

\section{CONCLUSION}

Neither the sex nor the hemispheric side and anatomic localization of ICH is a significant factor that influences the surgical outcome in patients with ICH. In contrast, the age and the clinical condition at the time of admission could give basic indications about the functional outcome in patients with $\mathrm{ICH}$ and the importance of age in clinical outcome may be explained in terms of main aggravating factors. The parameters such as larger volume of ICH, deep location of the hematoma, intraventricular spread of bleeding, and mass effect were significantly related to poor outcome in the elderly patients.

A higher percentage of patients with bad neurological outcome after the surgical intervention points to the fact that the treatment of the spontaneous $\mathrm{ICH}$ is still an unsolved clinical problem and the development of new treatment approaches as well as the discovery of new surgical techniques with larger efficiency in the evacuation of the hematoma are necessary, thus preventing the neurological deterioration in patients after ICH. 


\section{References}

1. Skidmore CT, Andrefsky J. Spontaneous intracerebral hemorrhage: epidemiology, pathophysiology and medical management. Neurosurg Clin N Am 2002; 13:281-8. https://doi.org/10.1016/S1042-3680(02)00019-0

2. Qureshi AI, Mendelow AD, Hanley DF. Intracerebral haemorrhage. Lancet 2009; 373: 163244.

https://doi.org/10.1016/S0140-6736(09)60371-8

3. Grysiewicz RA, Thomas K, Pandey DK. Epidemiology of ischemic and hemorrhagic stroke: incidence, prevalence, mortality, and risk factors. Neurol Clin 2008; 26:871-95. https://doi.org/10.1016/j.ncl.2008.07.003

4. Jakubovic R, Aviv RI. Intracerebral hemorrhage: toward physiological imaging of hemorrhage risk in acute and chronic bleeding. Front Neurol 2012; 3:86. https://doi.org/10.3389/fneur.2012.00086

5. Broderick JP, Adams HP, Barsan W et al. Guidelines for the management of spontaneous intracerebral hemorrhage: a statement for healthcare professionals from a special writing group of the Stroke Council, American Heart Association. Stroke 1999;30:905-15.

https://doi.org/10.1161/01.STR.30.4.905

6. van Asch CJ, Luitse MJ, Rinkel GJ et al. Incidence, case fatality, and functional outcome of intracerebral haemorrhage over time, according to age, sex, and ethnic origin: a systematic review and meta-analysis. Lancet Neurol 2010; 9:167-76. https://doi.org/10.1016/S1474-4422(09)70340-0

7. Broderick JP, Brott $\mathrm{T}$, Tomsick $\mathrm{T}$ et al. The risk of subarachnoid and intracerebral hemorrhage in blacks as compared with whites. N Engl J Med 1992; 326:733-6. https://doi.org/10.1056/NEJM199203123261103
8. Furlan AJ, Whisnant JP, Elveback LR. The decreasing incidence of primary intracerebral hemorrhage: a population study. Ann Neurol 1979; 5:367-73.

https://doi.org/10.1002/ana.410050410

9. Giroud M, Gras P, Chadan N et al. Cerebral hemorrhage in a French procpective population study. J Neurol Neurosurg Psychiatry 1991; 54:595-8. https://doi.org/10.1136/jnnp.54.7.595

10. D'Ambrosio A, Sughrue ME, Yorgason J et al. Decompressive hemicraniectomy for poor-grade aneurysmal subarachnoid hemorrhage patients with associated intracerebral hemorrhage: clinical outcome and quality of life assessment. Neurosurgery 2005; 56:12-9. https://doi.org/10.1227/01.NEU.0000144820.38439 .63

11. Keep RF, Hua Y, Xi G. Intracerebral haemorrhage: mechanisms of injury and therapeutic targets. Lancet Neurol 2012; 11:720-31. https://doi.org/10.1016/S1474-4422(12)70104-7

12. Wagner KR. Modeling intracerebral hemorrhage: glutamate, nuclear factor-kappa B signaling and cytokines. Stroke. 2007; 38(2 Suppl):753-8. https://doi.org/10.1161/01.STR.0000255033.02904. $\underline{\mathrm{db}}$

13.Adeoye O, Broderick JP. Advances in the management of intracerebral hemorrhage. Nat Rev Neurol 2010; 6: 593-601. https://doi.org/10.1038/nrneurol.2010.146

14.Broderick JP, Brott TG, Duldner JE et al. Volume of intracerebral hemorrhage: a powerful and easy-touse predictor of 30-day mortality. Stroke 1993; 24:987-3.

https://doi.org/10.1161/01.STR.24.7.987 
15.Brott T, Thalinger $\mathrm{K}$, Hertzberg V: Hypertension as a risk factor for spontaneous intracerebral hemorrhage. Stroke 1986; 17:1078-1083. https://doi.org/10.1161/01.STR.17.6.1078

16.Wang X, Arima H, Al-Shahi Salman R et al. Clinical Prediction Algorithm (BRAIN) to Determine Risk of Hematoma Growth in Acute Intracerebral Hemorrhage. Stroke. 2015; 46:376-81. https://doi.org/10.1161/STROKEAHA.114.006910

17. Mohr JP, Caplan LR, Melski JW. The Harvard Cooperative Stroke Registry: a prospective registry. Neurology 1978; 28:754-62. https://doi.org/10.1212/WNL.28.8.754

18.Song EC, Chu K, Jeong SW. Hyperglycemia exacerbates brain edema and perihematomal cell death after intracerebral hemorrhage. Stroke 2002; 34:2215-20. https://doi.org/10.1161/01.STR.0000088060.83709. 2C

19. Kaufmann HH. Treatment of deep spontaneous intracerebral hematomas: a review. Stroke 1993; 24: I101-6.

20. Kobayashi S, Sato A, Kageyama Yet al. Treatment of hypertensive cerebellar hemorrhage - surgical or conservative management? Neurosurgery 1994; 32:246-50.

https://doi.org/10.1227/00006123-199402000$\underline{00006}$

21.Mendelow AD, Gregson BA, Fernandes HM et al. STICH investigators. Early surgery versus initial conservative treatment in patients with spontaneous supratentorial intracerebral haematomas in the International Surgical Trial in Intracerebral Haemorrhage (STICH): a randomised trial. Lancet. 2005; 365:387-97.

https://doi.org/10.1016/S0140-6736(05)70233-6

22.Daverat P, Castel JP, Dartigues JF, Orgogozo JM. Death and functional outcome after spontaneous intracerebral hemorrhage. A prospective study of 166 cases using multivariate analysis. Stroke 1991; 22:1-6.

https://doi.org/10.1161/01.STR.22.1.1

23. Nakamura T, Xi G, Hua Yet al. Intracerebral hemorrhage in mice: model characterization and application for genetically modified mice. J Cereb Blood Flow 2004; 24:487-95. https://doi.org/10.1097/00004647-200405000$\underline{00002}$ 


\title{
Hirurški ishod kod bolesnika sa spontanim supratentorijalnim intracerebralnim krvarenjem
}

\author{
Vladimir Rendevski1,2, Dragan Stojanov,4, Boris Aleksovski5, Ana Mihajlovska Rendevska6, \\ Aleksandar Chaparoski ${ }^{1,2}$, Doga Ugurlar7, Vasko Aleksovski ${ }^{8}$, Natalija Baneva ${ }^{1,8}$, Icko Gjorgoski ${ }^{5}$ \\ 'Univerzitet "Sv. Ćirilo i Metodije", Medicinski fakultet, Skoplje, Makedonija \\ ${ }^{2}$ Univerzitetska klinika za neurohirurgiju, Skoplje, Makedonija \\ ${ }^{3}$ Univerzitet u Nišu, Medicinski fakultet, Niš, Srbija \\ ${ }^{4}$ Centar za radiologiju, Klinički centar Niš, Niš, Srbija \\ "Univerzitet "Sv. Ćirilo i Metodije", Fakultet za prirodne nauke i matematiku, Departman za opštu fiziologiju i \\ imunologiju, Skoplje, Makedonija \\ ${ }^{6}$ Univerzitetska klinika za radiologiju, Skoplje, Makedonija \\ ${ }^{7}$ Univerzitet medicinskih nauka, Bolnica za istraživanje i obuku Haseki, Istanbul, Turska \\ ${ }^{8}$ Univerzitetska klinika za neurologiju, Skoplje, Makedonija
}

\section{SAŽETAK}

Cilj rada bio je procena hirurškog ishoda kod bolesnika sa spontanim supratentorijalnim intracerebralnim krvarenjem (ICH) nakon hirurške intervencije u odnosu na inicijalne kliničke uslove, starost, pol, stranu hemisfere i anatomsku lokalizaciju ICH. Studija je uključila trideset osam hirurški tretiranih bolesnika sa spontanim supratentorijalnim intracerebralnim krvarenjem. Hirurški ishod je procenjen tri meseca nakon inicijalnog prijema, prema rezultatima (Glazgorske skale ishoda GOS). Hirurški tretman je bio uspešan kod 14 bolesnika ( $37 \%)$, dok je kod 24 bolesnika $(63 \%)$ bio neuspešan. Otkrili smo značajnu negativnu korelaciju između rezultata (Glazgorske skale kome GCS) na prijemu i rezultatima GOS-a nakon tri meseca, što ukazuje na lošiji neurološki ishod kod bolesnika sa početnim nižim rezultatima GCS-a. Na hirurški ishod kod bolesnika sa ICH nisu uticali pol, strana hemisfere i anatomska lokalizacija ICH, ali je starost bolesnika procenjena kao značajan faktor za njihov funkcionalni ishod, pri čemu je kod mlađih lečenje bilo uspešnije. Na hirurški ishod utiču početno kliničko stanje bolesnika kao i njihova starost. Lečenje ICH je i dalje je nerazjašnjen klinički problem i neophodno je razviti nove hirurške tehnike sa većom efikansošću u evakuaciji hematoma, čime se minimalno oštećuje normalno tkivo mozga, a smanjuje se i mogućnost postoperativnog krvarenja

Ključne reči: intracerebralno krvarenje, hirurški ishod, Glasgow Coma Scale, Glasgow Outcome Scale 